\title{
Evaluation of Education of The Use of Anthropometer Elderly Seats in Reducing Musculoskeletal Complaints and Improving The Elderly Satisfaction of Elderly in Posyandu
}

\section{Agus Sri Lestari ${ }^{*}$, Nyoman Ribek ${ }^{2}$, Dwi Rosmalawati ${ }^{3}$, Kt Gama ${ }^{4}$}

1,2 Politeknik Kesehatan Denpasar dan Malang

\section{A R T I C L E I N F 0}

Article history:

Received 15 August 2019

Received in revised Form 29 September 2019

Accepted 18 October 2019

Available online 29

November 2019

Keywords:

Musculoskeletal, Comfortable Feeling,

Chair Education for

Elderly and Posyandu

\begin{abstract}
A B S T R A C T
The background of the study was that the number of elderly people in the world and Indonesia in particular had increased and was a burden if their health conditions were not given enough attention. One of the issues of concern is the educational evaluation of the use of elderly anthropometer chairs can increase the comfort feeling of the elderly. The purpose of this study was to determine whether the educational use of anthropometer elderly chairs can reduce musculoskeletal complaints and increase the feeling of comfort in the elderly. The study was conducted at the Posyandu of Tumbak Bayuh Mengwi Village, Badung Regency, Bali Province and in the Posyandu RW 12, Bedali Village, UPT, Lawang Public Health Center, Malang Regency because they have similar characteristics. The method used is experimental (quasi experiment) using the same design as the subject (treatment by subject design). The results of the study concluded that musculoskeletal complaints in the initial condition with analysis using the t-pair test, obtained insignificant results $(p>0.05)$, meaning that there was no difference between the initial conditions. Analysis Test the difference in the final condition (post) obtained significant results $\left(p^{*}<0.05\right)$ meaning that there is a difference between the final condition and the t-pair test analysis on comfort shows a value of $p<0.05$, meaning that the elderly shows a sense of comfort using elderly anthropometer chair. Recommended for Puskesmas in posyandu to have anthropometer elderly chairs and educate their use in the elderly.
\end{abstract}




\section{Introduction}

Elderly is one of the issues faced by many countries in the world today. In 2015 the number of elderly people in the world has reached 901 million people and will continue to increase along with the target of SDGs (Sustainable Development Goals) in 2030 estimated to reach 1.4 billion people aged 60 years or older in the world (Kemenkes RI, 2015)

Elderly, is a phase of decreased mental and physical abilities, which begins with some changes in life.(Darmojo R.B \&Martono H.H., 2014). There are several countries to set the age limit for the elderly. In Indonesia, a person is considered elderly when he retires from his job at the age of 55 years, but in the United States a person is categorized as an elderly person at the age of 77 years preceded by pre-elderly masses, ie age 69-76 years, in Japan success actually starts at age 60 years, and many Japanese women who still work at the age of 60 years and over (Angga, 2010). The categorization of the elderly was also stated by Darmanto et al (2015), who divided the elderly into young elderly (65-74 years old) and older elderly (75 years old). tahun) (Darmanto, J Arneliwati, 2015) According to the World Health Organization (WHO), an elderly person is someone who has entered the age of 60 years and over and there is a process called Aging Process or the aging process. The aging process or aging is a process of slowly disappearing the ability of the tissue to repair itself and maintain normal structure and function so that it cannot withstand injury, including infection and repair the damage suffered. This aging process causes problems in his health which is characterized by the body's vulnerability to various diseases that can cause death, for example in the cardiovascular system, blood vessels, respiration, digestion, endocrine and so on. So that in general will affect the activity of daily living (Fatimah, 2010).

Indonesia is one of the countries entering the era of aging structured population (aging structured population), because the number of population aged 60 years and over has exceeded seven percent. Based on Indonesian Population Projection data, it is estimated that there are around 21 million elderly population in 2015. The number is predicted to increase to 33 million in 2025 and 48 million in 2035, or nearly 16 percent of the total population at that time (Bapenas, 2015). The five provinces with the highest number of elderly people in Indonesia in 2014 were in DI Yogyakarta, Central Java, East Java, Bali and North Sulawesi. The elderly population in Bali in 2014 was 1,177,200 people with ages ranging from 45 to less than 75 years. The five provinces with the highest number of elderly people in Indonesia in 2014 were in DI Yogyakarta, Central Java, East Java, Bali and North Sulawesi. The elderly population in Bali in 2014 was 1,177,200 people with ages ranging from 45 to less than 75 years (Dinas Kesehatan Provinsi Bali, 2016). East Java, especially Malang Regency has characteristics that are almost the same as the elderly in Bali. The large number of elderly population in the future can bring positive or negative impacts. The presence of elderly can have a positive impact if the elderly are in a healthy, active, and productive state. Complaints that are often found in the elderly in general musculoskeletal complaints which are usually called skeletal muscle complaints means discomfort to feel pain in the muscles and complaints can be temporary and can be permanent (Grandjean, 2007) Likewise in the elderly there are changes or deterioration in cognitive abilities including according to Nugroho are: 1) Easy to forget because memories do not function properly 2) Memories of things at a young age are better than those that occur in old age the first to be forgotten are the names 3) general orientation and perception of time and space or place are also backward, closely related to memory that has been retreated and also because views have narrowed 4) Despite having a lot of experience the scores achieved in intelligence tests are lower so that the elderly it's not easy to accept new things (Nugroho, 2008) Therefore the elderly need to have regular health checks to stay healthy, one of the secrets to staying healthy and fit according to Akhmadi is mental exercise, which is to empower the mind as important as physical exercise. (Ahkmadi, 2008). Therefore, elderly health needs to be considered because Article 5 of Law Number 13 Year 1998 regarding Elderly Welfare, states that the elderly have the same rights in social, national and state life. (Undang -undang N0.13,) . Services to get ease in the use of facilities and public infrastructure are intended to provide accessibility so as not to hamper the mobility of the elderly. One of the places to provide elderly health services is the elderly Posyandu. Elderly Posyandu is a communication forum, technology transfer and health services by the community and for people who have strategic value for the development of human resources especially the elderly usia (Depkes RI, 2000). The elderly Posyandu as a special place for plenary health services requires special attention and facilities, one of which is the anthropometric elderly chair which can increase comfort. In Posyandu, the elderly can be used as a place for health education for the elderly. According to Notoatmodjo Health education is an effort or activity to create community behavior conducive to health, which means that health education seeks to make people aware of or know how to care for their health, how to avoid or prevent things that harm their health and the health of others, where should seek treatment if sick, and so on. (Notoatmodjo, 2007). This health education, in its implementation is mostly played by elderly health cadres, Ughniyatul's research results 
explain that the role of health cadres is very strong proven to be related to the use of elderly Posyandu. (Ughniyatul M, 2016). Likewise, this study is supported by research that has been done, Anggraini who explained that the role of cadres is able to motivate the elderly to take advantage of the elderly Posyandu.(Anggraini,D.,Zulpadiana, 2015). Educational use of elderly anthropometer chairs can help hold on as a body support when undergoing height and knee height tests for body mass index (BMI) measurements and simple laboratory examinations and this is the basis for conducting research. This research was conducted at Tumbak Bayuh Mengwi Posyandu and Bedali Lawang Posyandu because it has almost the same characteristics. The purpose of the research is to evaluate whether the education of the use of elderly anthropometer chairs can improve patient comfort.

\section{Methods}

The research method used was quasi-experimental) using the same design (treatment by subject design) with measurements carried out twice, namely in the Pre and Post Periods (Pocock, 2008). The subjects in this study were elderly (elderly) in the village of Tumbak Bayuh Mengwi, Badung Regency and Posyandu in Bedali Lawang as many as 140 respondents with the inclusion criteria of elderly people aged 60 years and over, active elderly who were marked by carrying out independent and non-disabled activities which were marked by not there are physical and physical disabilities. Data analysis was performed by the Kolmogorov Smirnov test with a significance level of $p>0.05$ and the analysis of different tests using paired tests at a significant level of $5 \%(\alpha=0.05)$.

The subjects in this study were continued usis (Elderly) in Tumbak Bayuh Mengwi Village Badung Regency and Posyandu in Bedali Lawang as many as 140 respondents with the inclusion criteria of Elderly aged 60 years and older, active elderly who were characterized by carrying out independent and nondisabled activities which were marked by not there are physical and physical disabilities. Data analysis was performed by the Kolmogorov Smirnov test with a significance level of $p>0.05$ and the analysis of different tests using paired t tests at a significant level of $5 \%(\alpha=0.05)$

\section{Result And Discussion}

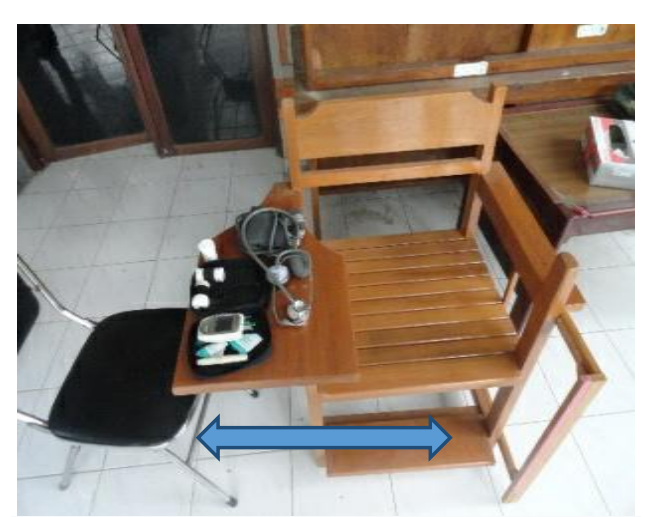

Picture from the front

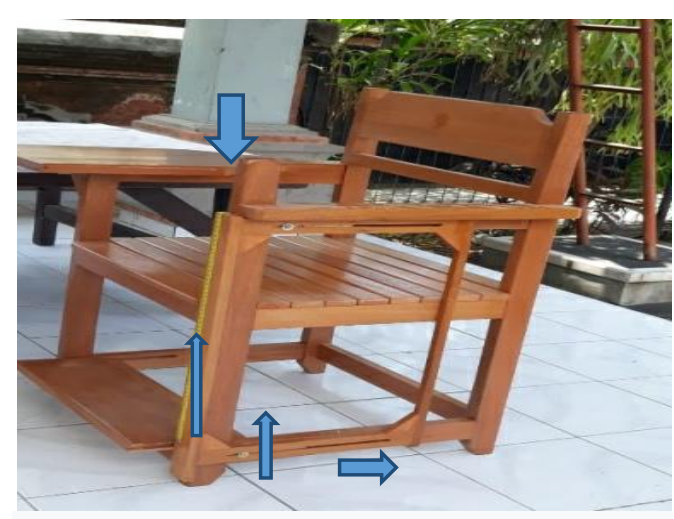

Picture from thefront Side

Figure 1. Anthropometer Elderly Chair Model

Table 1. Distribution of Respondents in Tumbak Bayuh and RT 12 Bedali

\begin{tabular}{clcccc}
\hline No & Responden & N & Average & Range & SB \\
\hline 1 & Tumbak Bayuh & 20 & 68,90 & $60-80$ & 7,2 \\
2 & Bedali & 20 & 62,55 & $60-70$ & 6,6 \\
\hline
\end{tabular}

Table 1 shows that the average age of the Elderly in Mengwi Bali is $69.92 \pm 7.2$. And in the elderly in Lawang Malang with a mean of $65.79 \pm 6.4$ years, this shows the subject is in old age. 
Table 2. Complaints of Musculoskeletal Subjects in Mengwi Badung Bali and RW 12 Bedali Lawang Village

\begin{tabular}{|c|c|c|c|c|c|c|c|c|c|}
\hline \multirow{2}{*}{ No } & \multirow{2}{*}{ Variable } & \multicolumn{4}{|c|}{ PI. Konvensional } & \multicolumn{4}{|c|}{ P II. Treatment } \\
\hline & & Minim & Max & Avarege & SB & Minim & Max & Avarege & SB \\
\hline 1 & $\begin{array}{l}\text { Complaints of } \\
\text { Muskulo } \\
\text { Skeletal } \\
\text { Before } \\
\text { physical } \\
\text { examination }\end{array}$ & 39,58 & 50,56 & 47,89 & 5,23 & 40,24 & 50,62 & 46,92 & 5,12 \\
\hline & $\begin{array}{l}\text { Complaints of } \\
\text { Muskulo }\end{array}$ & & & & & & & & \\
\hline 2 & $\begin{array}{l}\text { Skeletal after } \\
\text { physical } \\
\text { examination }\end{array}$ & 58,40 & 75,45 & 65,34 & 7,56 & 23,25 & 30,15 & 25,64 & 3,24 \\
\hline 3 & Difference & 18,82 & 24,89 & 17,45 & 2,33 & 16,99 & 20,47 & 21,28 & 1,88 \\
\hline
\end{tabular}

Table 2. shows that the results of the Period I (conventional) research on the average musculoskeletal complaints measurement was $47.89 \pm 5.23$ while after the physical examination the average was $65.34 \pm 7.56$. In Period II the results of the musculoskeletal complaints measurement before physical examination were in the average range of $59.45 \pm 5.05$ whereas after personal hygiene activities there was a decrease with an average of $46.92 \pm 5$.

Table 3. Results of Musculoskeletal Complaints Test with Paired Sample t-Test

\begin{tabular}{|c|c|c|c|c|c|c|c|}
\hline \multirow{2}{*}{ No } & \multirow{2}{*}{ Variable } & \multicolumn{2}{|c|}{ Period I } & \multicolumn{2}{|c|}{ Period II } & \multirow{2}{*}{ T value } & \multirow{2}{*}{$P$ value } \\
\hline & & Average & SB & Rerata & SB & & \\
\hline 1 & $\begin{array}{l}\text { Musculoskeletal } \\
\text { complaints } \\
\text { before activity }\end{array}$ & 47,89 & 5,31 & 46,92 & 5,05 & 0,419 & 0,682 \\
\hline 2 & $\begin{array}{l}\text { Musculoskeletal } \\
\text { complaints } \\
\text { after activity }\end{array}$ & 65,34 & 7,52 & 25,64 & 3,28 & 12,232 & 0,001 \\
\hline 3 & Deference & 17,45 & 8,94 & 21,28 & 5,80 & 12,525 & 0,001 \\
\hline
\end{tabular}

Table 3. shows Period I and Period II, the value of $t=0.419$ and the value of $p=0.682$. Test significantly $\left(\mathrm{p}^{*}<0.05\right)$, so that $\mathrm{HO}$ is rejected and Ha is accepted, meaning that there is a significant difference between Period I and Period II of the musculoskeletal complaints or a decrease of 39.7\%

Table 4. Comfort subjects in Mengwi Badung Bali and RW 12 Bedali Lawang Village

\begin{tabular}{ccccc}
\hline $\begin{array}{c}\text { Variable } \\
\text { Convenience }\end{array}$ & Minim & Maxi & Average & SB \\
\hline Period I & 5,33 & 9,00 & 8,31 & 1,6 \\
Period II & 14 & 19,38 & 16,498 & 1,8 \\
\hline
\end{tabular}

Table 4. shows that in the Period I study the subjects felt comfortable being at an average of 8,310 \pm 1.56 , while Period II was comfortable with a mean of $16,498 \pm 1,318$. 
Table 5. Results of Comfortable Difference in Mengwi Badung Bali and RW 12 Bedali Lawang Village

\begin{tabular}{|c|c|c|c|c|c|c|c|}
\hline \multirow[t]{2}{*}{ No } & \multirow[t]{2}{*}{ Description } & \multicolumn{3}{|c|}{ Period I } & \multirow{2}{*}{$\begin{array}{c}\begin{array}{c}\text { Period } \\
\text { II }\end{array} \\
\text { SB } \\
\end{array}$} & \multirow[t]{2}{*}{$\begin{array}{c}\mathbf{T} \\
\text { value }\end{array}$} & \multirow{2}{*}{$\begin{array}{c}P \\
\text { value }\end{array}$} \\
\hline & & Avareg & SB & Avareg & & & \\
\hline 1 & Convenience & 8,310 & 1,556 & 16,498 & 1,318 & $-14,459$ & 0,001 \\
\hline
\end{tabular}

Table 5 shows that the significance analysis with the $t$-paired test that the value of $t=-14,459$ and the value of $p=0.001$ means that the results of the $t$-pair test show a value of $p<0.05$, this indicates that there are significant differences between Period I and Period II so Ho was refused and Ha was accepted, which means the subject was in a comfortable condition carrying out a physical examination at the elderly Posyandu.

In this study an increase in the elderly period was found in the extreme age category which is above 75 years, age with the possibility of anatomic decline in physiological organs so that a decline in ability, capacity and capability. According to WHO's age limit a person with 60-70 years old is called elderly (Ratnawati, 2017) while the ages of 75 - 90 years belong to the Old group. It is stated that in general a person over the age of 60 years, his physical capacity will decrease by $25 \%$ marked by a decrease in muscle strength, while his motor ability decreases by $60 \%$, so that a person's physical capacity will be directly proportional to age (Manuaba, 2012)

The mean score of musculoskeletal complaints in conventional (pre) conditions in period I and period II was $47.89 \pm 5.23$ and $64.34 \pm 7.56$ respectively, while the mean musculoskeletal complaints in the final condition or after using the elderly chair (post) period I $46.92 \pm 5.12$ and period II 25.64 \pm 3.24 . Based on data distribution both in Period I and Period II, the initial (pre) and final (post) conditions are normal ( $p>0.05)$. So that the difference test between the two treatment periods can be used t-pair test. Analysis using t-pair test, the comparability of initial conditions (pre) in Period I and Period II obtained insignificant results ( $p>0.05)$. These results indicate that there is no difference between the initial conditions of Period I and Period II or it can be interpreted that the initial conditions of the two Periods are the same. Analysis of the Test differences in the final (post) condition obtained significant results ( $\mathrm{p}$ * $<0.05)$. This means that there is a significant difference between Period I and Period II of the musculoskeletal complaints. The magnitude of the decrease in musculoskeletal complaints after activity in Period II decreased by 39.7\%. The researchers mentioned that mukuloskeletal complaints are truly pure factors of the elderly that play a major role in the occurrence of falls, gait disorders (Adnyani, 2012) Elderly who have entered the age of 70 years are declared as Elderly in a high risk period. Usually there will be a decrease in various things including the level of independence in carrying out activities including coming to the posyandu (Maryam, 2011) ). Because of physical weakness as a physiological decrease in the body, the elderly need to get attention by seeking accessibility so that they feel comfortable to take a physical examination at the posyandu which includes high lutu, blood pressure checks, and / or examination of uric acid, blood sugar and cholesterol. In the results of comfort research both in Period I and Period II are normally distributed ( $p>0.05$ ), t-pair test analysis shows a value of $p<0.05$, stating that there is a significant difference between Period I and Period II. Period II gives a higher score than Period I, which indicates that the innovation of the intervention in the use of elderly anthropometer chairs has been proven to increase the elderly's sense of comfort. Anthropometry is a science that deals with aspects of human physical size. Elderly chairs are made using anthropometric measurements of sitting height, sitting shoulder height, sitting elbow height, poplital height and hand distance using 5th, 50th and 95th percentile percentiles (Iridastadi, 2014).

\section{Conclussion}

The results showed that of the 40 respondents getting better comfort than before, and there were differences in values between pre-test and post-test with a t value of $-14,459$. and the value of $p=0.001$ means that the $t$-pair test results show a value of $p<0.05$, this indicates that there is a significant difference between Period I and Period II so that it is concluded that Ho is rejected and Ha is accepted, which means the educational evaluation of the use of anthropometer elderly chairs is proven to reduce musculoskeletal complaints and increase comfort for the elderly. It is recommended that each puskesmas provide education on the use of anthropometer elderly chairs so that the elderly at posyandu activities feel comfortable and respected 


\section{Reference}

Adnyani, R. \& M. Y. (2012). Jatuh. GeriatriTeori Proses Menua. Jakarta: FKUI.

Ahkmadi. (2008). Menjaga Kesehatan Lanjut Usia Agar Tetap Prima. : F K UGM . Http: / / Akhmadi.multiply.com/journal/item/10.

Angga. (2010). Lansia dan Olahraga.

Anggraini, D., Zulpadiana, M. (2015). Faktor Dominan Lansia Aktif Mengikuti Kegiatan Posyandu di Dusun Ngentak. JNKI, Vol. 3, No.

Bapenas. (2015). Strategi kelanjutan Nasional 2015-2019. Jakarta.

Darmanto, J Arneliwati, W. R. (2015). Hubungan Kinerja kader Posyandu dengan Motivasi Lansia mengunjungi Posyandu lansia. Retrieved from Jom, vol 2.1

Darmojo R.B \&Martono H.H. (2014). GeriatriTeori Proses Menua. Jakarta: FKUI.

Depkes RI. (2000). Buku Pedoman Pemeliharaan Kesehatan Usia Lanjut. Jakarta: Dep.Kes RI.

Dinas Kesehatan Provinsi Bali. (2016). Profil Kesehatan Provinsi Bali Tahun 2015. Denpasar.

Fatimah. (2010). Gizi UasiLnjut. Jakarta: Erlangga.

Grandjean, E. (2007). Fitting the Task to The man. A Textbook of Occupational Ergonomics (Taylor \& F). London.

Iridastadi, H. dan Y. (2014). Ergonomi Suatu Pengantar. Bandung: PT Remaja Rosdakarya.

Kemenkes RI. (2015). GambaranKesehatanLanjut Usia di Indonesia. Jakarta: www.depkes.go.id.diaksespadatanggal 15 Oktober 2017.

Manuaba, A. (2012). A Total Approach In Ergonomics is A Must To Attain Human, Competitive, and Sustainable Work System and Products. Denpasar: Ergo Future.

Maryam. (2011). Mengenal Usia Lanjut dan Perawatannya. Jakarta.: Salemba Medika.

Notoatmodjo, S. (2007). Ilmu Kesehatan Masyarakat; Prinsip-prinsip Dasar. Jakarta: Rineka Cipta.

Nugroho, W. (2008). KeperawatanGerontikdanGeriatrik. Jakarta: EGC.

Ratnawati, E. (2017). Asuhan Keperawatan Gerontik. yogyakarta.

Ughniyatul M. (2016). Hubungan peran kader dengan keaktifan kunjungan posyandu lansia di Wilayah kerja puskesmas Godean.

Undang -undang N0.13. (n.d.). Undang-Undang Kesejahteraan Lanjut Usia. 